\title{
Pengaruh Media Komik Berwarna terhadap Hasil Belajar IPA Siswa
}

\author{
Fika Andriyani ${ }^{1}$, Ni Nyoman Kusmariyatni ${ }^{2}$ \\ ${ }^{12}$ Jurusan Pendidikan Guru Sekolah Dasar, Fakultas IImu Pendidikan \\ Universitas Pendidikan Ganesha \\ Singaraja, Indonesia \\ e-mail: fikaandriyani2410gmail.com
}

\begin{abstract}
Abstrak
Penelitian ini bertujuan untuk mengetahui perbedaan yang signifikan hasil belajar IPA antara kelompok siswa yang dibelajarkan dengan menggunakan media komik berwarna dan kelompok siswa yang dibelajarkan tanpa menggunakan media komik berwarna pada siswa kelas II SD di Gugus II Kubutambahan, Tahun Pelajaran 2017/2018. Jenis penelitian ini adalah penelitian eksperimen semu, dengan desain Non Equivalen Post Test Only Control Group Desain. Populasi dalam penelitian adalah seluruh siswa kelas II SD di Gugus II Kubutambahan tahun pelajaran 2017/2018 yang berjumlah 191 siswa. Sampel penelitian sebagai kelas eksperimen yaitu kelas II SDN 04 Kubutambahan yang berjumlah 27 siswa dan kelas II SDN 07 Kubutambahan sebagai kelas kontrol yang berjumlah 24 siswa, sampel diperoleh dengan teknik random sampling. Data hasil belajar IPA dikumpulkan dengan instrumen tes pilihan ganda. Selanjutnya, dianalisis menggunakan teknik statistik deskriptif dan statistik inferensial (uji-t). Berdasarkan hasil perhitungan uji-t diperoleh $t_{\text {hitung }}$ yaitu sebesar 4,75 lebih besar dari $t_{\text {tabel }}$ yaitu 1,67 yang diuji pada taraf signifikan $5 \%$ dengan derajat kebebasan 49 . Hal ini berarti terdapat perbedaan yang signifikan hasil belajar IPA antara kelompok siswa yang dibelajarkan dengan menggunakan media komik berwarna (kelompok eksperimen) dan kelompok siswa yang dibelajarkan tanpa menggunakan media komik berwarna (kelompok kontrol). Selain itu, berdasarkan analisis deskriptif diperoleh bahwa rata-rata hasil belajar IPA kelompok eksperimen yaitu 22,89 > rata-rata hasil belajar IPA kelompok kontrol yaitu 18,50. Dengan demikian, dapat disimpulkan bahwa penggunaan media komik berwarna berpengaruh secara signifikan terhadap hasil belajar IPA siswa kelas II SD di Gugus II Kecamatan Kubutambahan Tahun Pelajaran 2017/2018.
\end{abstract}

Kata Kunci: Hasil Belajar, IPA, Media Komik Berwarna

\begin{abstract}
This research is aimed to knowing the significant difference of the science learning outcomes between the group of students that learning with colored comic media and the group of students that learning without colored comic media to the II grade students II Kubutambahan in academic year 2017/2018. This research was quasi experiment with the design which was "non equivalen post test only control group design". The population in this research all students class II SD in Gugus II Kubutambahan in academic year 2017/2018 amounts 191 students. The sample this research as a experimental class is students grade II from SDN 04 Kubutambahan amounts 27 students and students grade II from SDN 07 Kubutambahan as a control class amounts 24 students, the sample of study was chosen by random Sampling technique. The data collection in this research use method with multiple choice test instrument. The learning outcomes was analyzed by descriptive statistics and inferential statistics (uji-t). Based on t-test calculations obtained $t_{\text {arithmetic }}$ is 4,75 is greater than $t_{\text {table }}$ is 1,67 tested with a significant level of $5 \%$ with degrees of freedom 49 . This means the are significant differences in learning outcomes between group of students who learned by usng colored comic media (experimental group) and group of students who were taught without using color comic media (control group). Besides, based on descriptive analysis it was found that the average of experimental group learning result was 22,89 > the mean of science control group learning outcome was 18,50. So it can be concluded that the the use of colored comic media have a significant effect to the result of science learning grade II elementary school in Cluster II District of Kubutambahan Lesson year 2017/2018.
\end{abstract}

Keywords: The Learning Outcomes, Science, Colored Comic Media 


\section{Pendahuluan}

Pembelajaran mengacu pada segala kegiatan yang berpengaruh langsung terhadap proses belajar siswa, sehingga siswa juga harus aktif dalam kegiatan pembelajaran. Menurut Tim Pengembang MKDP Kurikulum dan Pembelajaran (2011) kegiatan pembelajaran bukan lagi sekedar menyiapkan pengajaran dan melaksanakan prosedur mengajar dalam pembelajaran tatap muka. Namun, kegiatan pembelajaran lebih kompleks lagi dan dilaksanakan dengan pola-pola pembelajaran yang bervariasi.

Pembelajaran yang berkualitas dimulai dari pendidik (guru) yang berkualitas. seorang pendidik harus penuh dengan inovasi dalam menciptakan suasana belajar yang menyenangkan, dapat meningkatkan minat, motivasi dan hasil belajar peserta didik. Menurut Suwatra ,dkk (2015) proses pembelajaran merupakan adanya interaksi yang terjalin antara guru dan siswa. Kualitas hubungan baik atau buruk saat pembelajaran sangat ditentukan oleh seorang pendidik (guru) dalam mengajar dan siswa dalam belajar. Menurut Khusniati (2014) pembelajaran di Sekolah Dasar dalam kurikulum 2013 menerapkan pembelajaran tematik terpadu yang sangat disarankan penggunaannya dengan nama pembelajaran tematik terintegrasi. Pendekatan pembelajaran tematik integratif ini sebelumnya telah dikembangkan khusus untuk peserta didik berbakat dan bertalenta (gifted and talented), cerdas, program perluasan belajar, dan peserta didik yang belajar cepat. Dalam kurikulum 2013, peserta didik membutuhkan kesempatan-kesempatan tambahan (additional opportunities) agar dapat memanfaatkan bakat dan talentanya, menyediakan waktu bersama yang lain untuk secara cepat mengkonseptualisasi dan mensintesis. Pembelajaran di sekolah dasar yang terintegratif, diharapkan dapat mencapai kompetensi yang berimbang antara sikap (attitude), keterampilan (skill) dan pengetahuan (knowledge) yang dicapai melalui pembelajaran yang holistik dan menyenangkan. Keberhasilan guru dalam mengimplementasikan kurikulum 2013 diantaranya apabila mampu mengkaji, menggunakan, dan melengkapi buku guru sebagai sumber belajar utama.

Kualitas hubungan dalam pembelajaran dapat menentukan keberhasilan proses pembelajaran yang efektif. Mengingat begitu penting hubungan guru dan siswa dalam pembelajaran dalam menentukan keberhasilan belajar, maka guru harus mampu menciptakan hubungan yang positif dan mampu menciptakan suasana pembelajaran yang kondusif. Sehingga, seorang pendidik harus mampu menciptakan suasana belajar bermakna dan kondusif. Belajar bermakna menurut Ausubel (dalam Susanto, 2016). suatu proses penggabungan informasi baru yang diperoleh dengan struktur pengertian yang sudah dimiliki oleh seseorang yang sedang belajar. Sedangkan, pembelajaran yang kondusif menurut Kamus Besar Bahasa Indonesia (KBBI) kondisi tenang, mudah diatur, dan mendukung untuk terjadinya suatu aktivitas atau tujuan tertentu.

Pembelajaran demikian, diharapkan dapat terjadi pada semua mata pelajaran di sekolah termasuk mata pelajaran IPA. Menurut Samatowa (2006) IPA merupakan mata pelajaran yang mengaitkan kehidupan sehari-hari dengan proses pembelajaran, mata pelajaran IPA juga dapat membantu mengenal lingkungan secara logis dan sistematis. Pembelajaran IPA harus mencakup kesesuaian antara situasi belajar anak dengan situasi kehidupan nyata di masyarakat dan pengalaman langsung. Menurut Sulthon (2016) Pembelajaran IPA tidak bisa dengan cara menghafal atau pasif mendengarkan guru menjelaskan konsep namun siswa sendiri yang harus melakukan pembelajaran melalui percobaan, pengamatan maupun bereksperimen secara aktif yang akhirnya akan terbentuk kreativitas dan kesadaran untuk menjaga dan memperbaiki gejala-gejala alam yang terjadi untuk selanjutnya membentuk sikap ilmiah yang pada gilirannya akan aktif untuk menjaga kestabilan alam ini secara baik dan lestari. Menurut Sumiyadi (2015) Penguasaan IPA melalui pembelajaran secara teoritis sangat ditentukan oleh kemampuan dan kreatifitas siswa dalam menguasai keterampilan proses sains. Siswa yang mempunyai keterampilan proses bagus maka prestasi akademiknya juga bagus.

Secara garis besar hakikat IPA memiliki tiga komponen yaitu IPA sebagai produk, IPA sebagai Proses, dan IPA sebagai sikap ilmiah. IPA sebagai produk berkaitan dengan hasil penelitian yang dilakukan oleh ilmuwan-ilmuwan dan membentuk sebuah konsep yang telah dikaji. IPA sebagai proses merujuk pada keterampilan untk dapat mengkaji fenomenafenomena alam dengan cara tertentu. IPA sebagai sikap ilmiah merrupakan sikap ilmiah yang dimiliki para ilmuwan dalam menggali dan mencari pengetahuan baru (Bundu, 2006).

Pembelajaran IPA harus disesuaikan dengan tingkat perkembangan kognitif, minat, dan lingkungan siswa sendiri. Dalam setiap pembelajaran IPA kegiatan bertanya salah satu bagian yang penting, melalui bertanya siswa akan dilatih untuk menyampaikan gagasan yang relevan 
terhadap permasalahan atau materi yang disampaikan. Oleh karena itu, pembelajaran IPA di SD harus dirancang secara menarik, menyenangkan, menimbulkan rasa ingin tahu siswa, antusias siswa, memperhatikan perkembangan siswa, dan terjadinya interaksi multi arah.

Namun fakta yang ditemukan di sekolah dasar pembelajaran IPA masih belum sesuai harapan. Hal ini diketahui dari hasil wawancara, observasi, dan pencatatan dokumen terhadap 6 orang guru kelas II. Berdasarkan hasil wawancara dengan 6 wali kelas II di SD Gugus II Kecamatan Kubutambahan pada tanggal 3 dan 8 Januari 2018 yaitu, (1) empat dari enam orang guru menyatakan dalam pembelajaran IPA jarang menggunakan media karena keterbatasan media dan tidak memiliki waktu untuk membuat media (2) enam orang guru sulit untuk mengendalikan siswa agar terfokus dalam pembelajaran, hal ini dikarenakan siswa yang bosan, sehingga siswa mencari kegiatan lain yang menyenangkan seperti bercanda dengan teman dan tidak memperhatikan pelajaran. Sehingga, pembelajaran tidak berjalan dengan maksimal dan menyebabkan kurangnya pemahaman akan konsep materi yang dipelajari khususnya IPA tentunya akan berpengaruh pada perolehan hasil belajar.

Hal ini didukung oleh Widayati (dalam Kompasiana, 2013) menyatakan, dengan penggunaan media pembelajaran dalam pembelajaran, terutama untuk tingkat sekolah dasar sangatlah penting. Karena dengan adanya penggunaan media sangat membantu siswa untuk dapat memahami konsep tertentu. Pada masa ini siswa masih berpikir konkret dan belum mampu berpikir abstrak, untuk itu guru seharusnya memilih dan menggunakan media yang sesuai dengan perkembangan siswa dan sesuai dengan tujuan pembelajaran.

Hasil wawancara diperkuat dengan hasil observasi yang dilaksanakan pada tanggal 3,6,8, dan 12 Januari 2018 di SD Gugus II Kecamatan Kubutambahan. Melakukan observasi dengan mengamati proses pembelajaran di kelas II SD gugus II diperoleh beberapa masalah dari hasil observasi yaitu: (1) siswa kurang bersemangat dalam mengikuti pembelajaran, (2) siswa sering tidak fokus pada pembelajaran dan mencari kesenangannya yang lain seperti jalan-jalan dan bercanda dengan temannya, (3) siswa merasa bosan dan mengantuk dikelas, (4) guru jarang menggunakan media pembelajaran dalam proses pembelajaran khususnya mata pelajaran IPA.

Selain wawancara dan observasi, dilakukan pencatatan dokumen pada tanggal 4 Januari 2018. Adapun rata-rata nilai UAS mata pelajaran IPA siswa kelas II SD Gugus II Kecamatan Kubutambahan dengan KKM 65-75, disajikan pada Tabel 1.

Tabel 1. Nilai Rata-rata UAS IPA Kelas II di Gugus II Kubutambahan

\begin{tabular}{ccccccccc}
\hline \multirow{2}{*}{ No. } & \multirow{2}{*}{ Nama Sekolah Dasar } & \multirow{2}{*}{ KKM } & \multirow{2}{*}{ Jumlah } & \multicolumn{2}{c}{ Tuntas } & \multicolumn{2}{c}{ Tidak Tuntas } \\
\cline { 5 - 8 } & & IPA & siswa & Siswa & $\%$ & Siswa & $\%$ \\
\hline 1 & SDN 02 Kubutambahan & 75 & 29 & 7 & 24,14 & 22 & 75,86 \\
2 & SDN 03 Kubutambahan & 75 & 33 & 6 & 18,18 & 27 & 81,82 \\
3 & SDN 04 Kubutambahan & 65 & 27 & 5 & 18,52 & 22 & 81,48 \\
4 & SDN 05 Kubutambahan & 75 & 35 & 9 & 25,72 & 26 & 74,28 \\
5 & SDN 06 Kubutambahan & 69 & 44 & 7 & 15,91 & 37 & 84,09 \\
6 & SDN 07 Kubutambahan & 65 & 24 & 7 & 29,16 & 17 & 70,84 \\
\hline
\end{tabular}

Pada Tabel 1 diketahui nilai rata-rata ulangan semester untuk mata pelajaran IPA belum optimal karena masih ada siswa yang nilainya kurang dari kriteria ketuntasan minimal (KKM) yang sudah ditetapkan di setiap satuan pendidikan.

Salah satu upaya untuk mengatasi permasalahan tersebut, yaitu guru mampu merancang pembelajaran yang inovatif agar siswa dapat terlibat aktif, membangkitkan minat dan perhatian siswa agar terfokus dalam dalam belajar. Salah satu faktor yang mempengaruhi keberhasilan dalam pembelajaran adalah penggunaan media pembelajaran yang sesuai dan menciptakan pembelajaran yang menyenangkan, menantang, menarik, aktif, dapat menimbulkan, dan media merupakan alat bantu yang dapat membantu seorang guru dan siswa dalam mempermudah proses pembelajaran (Wati, 2016). Pembelajaran harus disertai dengan menggunakan media pembelajaran karena siswa SD masih berada pada tahap operasional konkret. Menurut Rusman (2015) tahap operasional konkret adalah tahap perkembangan kognitif anak dimulai dari usia 6 sampai 12 tahun. Pada tahap ini anak berpikir terbatas pada objek yang diamati secara langsung. Tahap operasional konkret berarti tahap dimana siswa belajar melalui benda konkret atau nyata karena siswa SD belum dapat membayangkan sesuatu yang bersifat abstrak. Dengan demikian, pembelajaran yang baik dan memperhatikan tahap perkembangan siswa dapat membantu siswa memperoleh hasil belajar yang maksimal. 
Penelitian dengan menerapkan media komik sudah pernah dilakukan oleh peneliti lain, yaitu oleh Novianti (2010) dengan mengembangkan media pembelajaran komik dan diterapkan. Dari penelitian yang dilakukan oleh Novianti maka dapat disimpulkan pemahaman siswa kelas V SDN Ngembung terhadap soal cerita pada Bab Pecahan telah mengalami peningkatan setelah memanfaatkan Media Komik Pembelajaran. Pembelajaran dengan menggunakan media komik dapat menambah daya tarik siswa dengan adanya fill atau pewarnaan yang serasi serta variasi gambar yang menarik.

Sehubungan dengan hal tersebut maka media pembelajaran komik berwarna sangat cocok untuk diterapkan sehingga akan berdampak pada peningkatan hasil belajar IPA. Berdasarkan pemikiran tersebut, maka dilakukan penelitian yang berjudul "Pengaruh Media Komik Berwarna Terhadap Hasil Belajar IPA Kelas II SD di Gugus II Kecamatan Kubutambahan Tahun Pelajaran 2017/2018".

Tujuan penelitian ini adalah Untuk mengetahui perbedaan yang signifikan hasil belajar IPA siswa yang dibelajarkan dengan menggunakan media komik berwarna dengan kelompok siswa yang dibelajarkan tanpa menggunakan media komik berwarna pada siswa kelas II SD di gugus II Kecamatan Kubutambahan tahun pelajaran 2017/2018.

\section{Metode}

Pada tabel 1 diketahui nilai rata-rata ulangan semester untuk mata pelajaran IPA belum optimal karena masih ada siswa yang nilainya kurang dari kriteria ketuntasan minimal (KKM) yang sudah ditetapkan di setiap satuan pendidikan.

Salah satu upaya untuk mengatasi permasalahan tersebut, yaitu guru mampu merancang pembelajaran yang inovatif agar siswa dapat terlibat aktif, membangkitkan minat dan perhatian siswa agar terfokus dalam dalam belajar. Salah satu faktor yang mempengaruhi keberhasilan dalam pembelajaran adalah penggunaan media pembelajaran yang sesuai dan menciptakan pembelajaran yang menyenangkan, menantang, menarik, aktif, dapat menimbulkan, dan media merupakan alat bantu yang dapat membantu seorang guru dan siswa dalam mempermudah proses pembelajaran (Wati, 2016). Pembelajaran harus disertai dengan menggunakan media pembelajaran karena siswa SD masih berada pada tahap operasional konkret. Menurut Rusman (2015) tahap operasional konkret adalah tahap perkembangan kognitif anak dimulai dari usia 6 sampai 12 tahun. Pada tahap ini anak berpikir terbatas pada objek yang diamati secara langsung. Tahap operasional konkret berarti tahap dimana siswa belajar melalui benda konkret atau nyata karena siswa SD belum dapat membayangkan sesuatu yang bersifat abstrak. Dengan demikian, pembelajaran yang baik dan memperhatikan tahap perkembangan siswa dapat membantu siswa memperoleh hasil belajar yang maksimal.

Penelitian dengan menerapkan media komik sudah pernah dilakukan oleh peneliti lain, yaitu oleh Novianti (2010) dengan mengembangkan media pembelajaran komik dan diterapkan. Dari penelitian yang dilakukan oleh Novianti maka dapat disimpulkan pemahaman siswa kelas V SDN Ngembung terhadap soal cerita pada Bab Pecahan telah mengalami peningkatan setelah memanfaatkan Media Komik Pembelajaran. Pembelajaran dengan menggunakan media komik dapat menambah daya tarik siswa dengan adanya fill atau pewarnaan yang serasi serta variasi gambar yang menarik.

Sehubungan dengan hal tersebut maka media pembelajaran komik berwarna sangat cocok untuk diterapkan sehingga akan berdampak pada peningkatan hasil belajar IPA. Berdasarkan pemikiran tersebut, maka dilakukan penelitian yang berjudul "Pengaruh Media Komik Berwarna Terhadap Hasil Belajar IPA Kelas II SD di Gugus II Kecamatan Kubutambahan Tahun Pelajaran 2017/2018".

Tujuan penelitian ini adalah Untuk mengetahui perbedaan yang signifikan hasil belajar IPA siswa yang dibelajarkan dengan menggunakan media komik berwarna dengan kelompok siswa yang dibelajarkan tanpa menggunakan media komik berwarna pada siswa kelas II SD di gugus II Kecamatan Kubutambahan tahun pelajaran 2017/2018. 
Tabel 2. Sampel Penelitian

\begin{tabular}{|c|c|c|c|c|c|}
\hline No & Sampel & Kelompok & Media Pembelaja & & Jumlah Siswa \\
\hline 1 & $\begin{array}{l}\text { Kelas II SDN } 04 \\
\text { Kubutambahan }\end{array}$ & Eksperimen & $\begin{array}{l}\text { Pembelajaran meng } \\
\text { Media Komik Berwarna }\end{array}$ & inakan & 27 \\
\hline 2 & $\begin{array}{l}\text { Kelas II SDN } 07 \\
\text { Kubutambahan }\end{array}$ & Kontrol & $\begin{array}{l}\text { Pembelajaran tanpa } \\
\text { Komik Berwarna }\end{array}$ & Media & 24 \\
\hline \multicolumn{5}{|c|}{ Total Sampel } & 51 \\
\hline
\end{tabular}

Metode yang digunakan untuk mengumpulkan data hasil belajar IPA yaitu menggunakan metode tes dengan instrumen pilihan ganda tes tersebut diberikan pada pertemuan ke 8 setelah diberlakukannya pembelajaran menggunakan media komik berwarna dan pembelajaran tanpa media komik berwarna. Untuk mengumpulkan data hasil belajar tersebut, dalam penelitian ini digunakan metode tes. Metode tes yang digunakan dalam penelitian ini adalah cara memperoleh data berbentuk suatu tugas yang dilakukan atau dikerjakan oleh seseorang dan menghasilkan suatu data berupa skor (interval). Digunakan teknik pengukuran ini karena sesuai dengan bentuk penelitian yang digunakan yaitu penelitian eksperimen yang bertujuan untuk melihat hasil belajar siswa melalui pengaruh perlakuan yang diberikan. Insrumen perlu diujicobakan terlebih dahulu untuk mengetahui kelayakan instrumen tersebut.

Sebuah intrumen dapat dikatakan layak apabila memenuhi syarat instrumen yang baik. Sehingga perlu dilakukan uji validitas, uji reliabilitas tes, uji daya beda tes ,dan uji kesukaran tes. Uji validasi isi Untuk mengumpulkan data hasil belajar tersebut, dalam penelitian ini digunakan metode tes. Metode tes yang digunakan dalam penelitian ini adalah cara memperoleh data berbentuk suatu tugas yang dilakukan atau dikerjakan oleh seseorang dan menghasilkan suatu data berupa skor (interval). Digunakan teknik pengukuran ini karena sesuai dengan bentuk penelitian yang digunakan yaitu penelitian eksperimen yang bertujuan untuk melihat hasil belajar siswa melalui pengaruh perlakuan yang diberikan.

Uji validasi isi dilakukan dengan melakukan konsultasi kepada para dua pakar (judges) terkait soal yang mengukur hasil belajar dengan hasil perhitungan 1,00 koefisien tersebut berada pada kategori validitas isi sangat baik, kemudian soal diujicobakan di sekolah. Berdasarkan hasil dengan jumlah responden 50 siswa didapatkan 36 butir tes valid dari 40 butir soal yang diujicobakan. Selanjutnya dari hasil uji reliabilitas diperoleh koefisien reliabilitas sebesar 0,91 kategori sangat tinggi.Berdasarkan hasil uji daya beda tes hasil belajar IPA diperoleh 6 butir soal terklarifikasi kurang baik, 13 butir soal terklarifikasi cukup baik, 18 butir soal terklarifikasi baik, dan 3 butir soal terklarifikasi sangat baik. Hasil perhitungan daya beda tes (Dp) adalah 0,393 dengan kategori cukup baik. Selanjutnya berdasarkan uji tingkat kesukaran tes hasil belajar IPA dari 40 butir soal diperoleh 19 butir soal mudah, 20 butir soal kategori sedang, dan 1 butir soal kategori sukar. Hasil perhitungan taraf kesukaran (Pp) adalah 0,69 dengan kategori sedang.

Pada penelitian ini digunakan dua metode analisis, yaitu metode analisis statistik deskriptif dan metode analisis inferensial. Metode analisis deskriptif digunakan untuk mengetahui tinggi rendahnya kualitas dari variabel penelitian. Analisis deskriptif dilakukan dengan menghitung mean, median, modus, varians, dan standar deviasi. Sedangkan metode analisis statistik inferensial dilakukan dengan uji normalitas distribusi data dan homogenitas varians. Metode analisis yang digunakan untuk menguji hipotesis dalam penelitian ini adalah uji-t sampel independent dengan polled varians. Sebelum dilakukan uji hipotesis terlebih dahulu dilakukan uji prasyarat analisis meliputi uji normalitas distribusi data dengan menggunakan uji Chi-Kuadrat dan uji homogenitas varians dengan menggunakan uji-F.

\section{Hasil dan Pembahasan}

Pengukuran hasil belajar IPA dilakukan terhadap siswa pada masing-masing kelompok kelas yaitu kelas eksperimen dan kelas kontrol dengan menggunakan soal pilihan ganda sebanyak 30 butir pertanyaan. Data hasil belajar IPA kelompok eksperimen diperoleh melalui post test terhadap 27 siswa. Hasil test menunjukkan bahwa skor tertinggi adalah 29 dan skor terendah adalah 13. Dari skor yang diperoleh dapat dideskripsikan, yaitu mean sebesar 22,89, median adalah 23,25 , modus adalah 25,37, varians adalah 15,49, standar deviasi 3,93 , skor maksimum 29, skor minimum 13, dan retangan adalah 16 .

Data hasil belajar siswa yang dibelajarkan menggunakan media komik berwarna (kelompok eksperimen), maka dapat dilihat siswa mendapatkan skor terendah pada rentangan 
13-15 sebanyak 1 orang, siswa mendapatkan skor pada rentangan 16-18 sebanyak 3 orang, siswa mendapatkan skor pada rentangan 19-21 sebanyak 6 orang. Siswa mendapatkan skor pada rentangan 22-24 sebanyak 6 orang. Siswa mendapatkan skor pada rentangan 25-27 sebanyak 8 orang dan siswa yang mendapatkan skor pada rentangan 28-30 sebanyak 3 orang. Data hasil belajar IPA kelompok eksperimen, dapat disajikan ke dalam bentuk grafik kurva polygon seperti pada gambar 1.

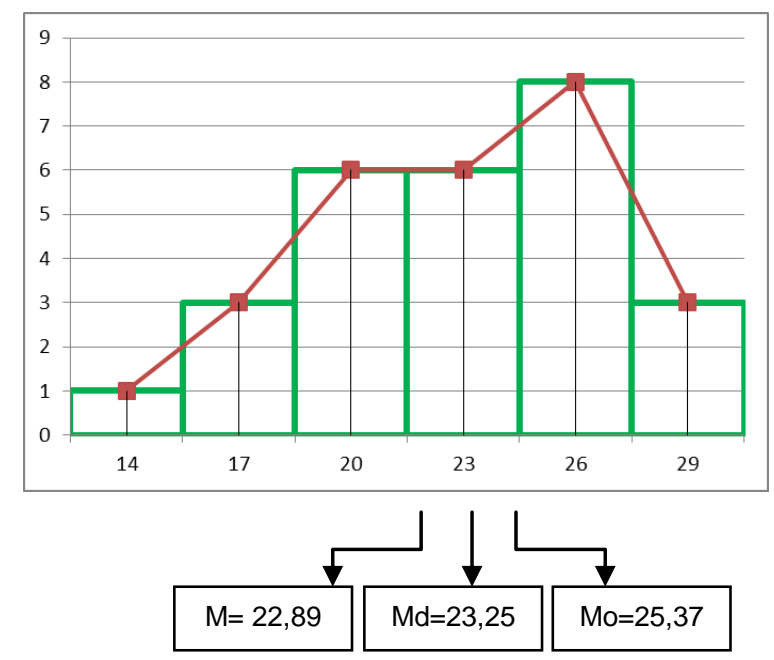

\section{Gambar 1. Grafik Kurva Poligon Data Hasil Post test Kelompok Eksperimen}

Berdasarkan grafik kurva di atas, diketahui bahwa modus lebih besar dari median dan median lebih besar dari mean (Mo>Md $>M$ ). Dengan demikian kurva diatas adalah kurva juling negatif yang berarti bahwa sebagian besar skor cenderung tinggi.

Data hasil belajar IPA kelompok kontrol diperoleh melalui post test terhadap 24 orang siswa. Hasil test menunjukkan bahwa skor tertinggi adalah 25 dan skor terendah 9. Dari skor yang diperoleh dapat dideskripsikan, yaitu mean sebesar 18,5, median adalah 17,50, modus adalah 16,25 , varians adalah 16,89, standar deviasi 4,11 , skor maksimum 25 , skor minimum 9 , dan retangan adalah 16 .

Data hasil belajar siswa yang dibelajarkan tanpa menggunakan media komik berwarna (kelompok kontrol), maka dapat dilihat siswa mendapatkan skor terendah pada rentangan 9-11 sebanyak 1 orang, siswa mendapatkan skor pada rentangan 12-14 sebanyak 2 orang, siswa mendapatkan skor pada rentangan 15-17 sebanyak 9 orang. Siswa mendapatkan skor pada rentangan 18-20 sebanyak 4 orang. Siswa mendapatkan skor pada rentangan 21-23 sebanyak 4 orang dan siswa yang mendapatkan skor pada rentangan $24-26$ sebanyak 4 orang. Data hasil belajar IPA kelompok kontrol, dapat disajikan ke dalam bentuk grafik kurva polygon seperti pada gambar 2.

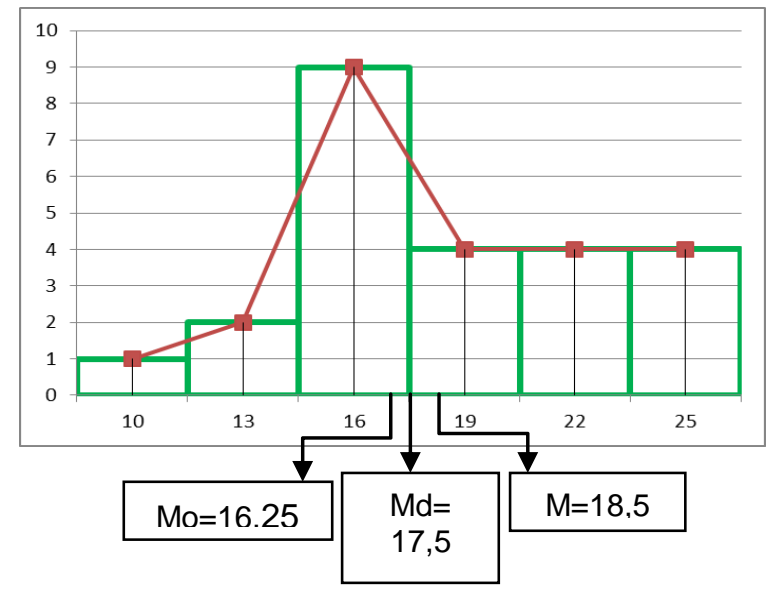

Gambar 2. Grafik Kurva Poligon Data Hasil Post test Kelompok Kontrol 
Berdasarkan grafik di atas, diketahui bahwa modus lebih besar dari median dan median lebih besar dari mean (Mo>Md>M). Dengan demikian kurva diatas adalah kurva juling positif yang berarti bahwa sebagian besar skor cenderung rendah.

Selanjutnya sebelum melakukan uji hipotesis, dilakukan uji normalitas sebaran data dan homogenitas kelompok varians. Uji normalitas data penguasaan kompetensi pengetahuan IPA siswa menggunakan rumus analisis Chi-Kuadrat $\left(X^{2}\right)$ pada taraf signifikan $5 \%$ dan derajat kebebasan $(\mathrm{dk})=\mathrm{n}-1$. Berdasarkan tabel nilai-nilai Chi-Kuadrat diperoleh $X_{\text {tabel }}^{2}$ sebesar 7,815, dengan kriteria sebagai berikut: 1) Apabila harga $X_{\text {hitung }}^{2}<7,815$ maka $H_{0}$ diterima atau $H_{1}$ ditolak sehingga sebaran frekuensi penguasaan kompetensi pengetahuan IPA pada masingmasing kelompok dapat dikategorikan berdistribusi normal. 2) Apabila harga $X_{\text {hitung }}^{2}>7,815$ maka $\mathrm{H}_{0}$ ditolak atau $\mathrm{H}_{1}$ diterima sehingga sebaran frekuensi penguasaan kompetensi pengetahuan IPA pada masing-masing kelompok dapat dikategorikan tidak berdistribusi normal.

Berdasarkan analisis data uji normalitas yang dilakukan pada hasil belajar IPA di kelas eksperimen diperoleh $X_{\text {hitung }}^{2}=\sum \frac{\left(f_{0}-f_{e}\right)^{2}}{f_{e}}=1,495$. Harga $X_{\text {hit }}^{2}$ yang diperoleh dari kelompok eksperimen adalah $X_{\text {hitung }}^{2}=\sum \frac{\left(f_{0}-f_{e}\right)^{2}}{f_{e}}=1,495$. Harga tersebut kemudian dibandingkan dengan harga $X_{\text {tabel }}^{2}$ dengan $\mathrm{dk}=3$ dan taraf signifikan $5 \%$ sehingga diperoleh harga $X_{\text {tabel }}^{2}=$ 7,815 , karena $X_{\text {hitung }}^{2}<X_{\text {tabel }}^{2}(1,495<7,815)$ maka $\mathrm{H}_{0}$ diterima atau $\mathrm{H}_{\mathrm{a}}$ ditolak. Ini berarti sebaran data hasil belajar IPA kelompok eksperimen berdistribusi normal. Sedangkan analisis data uji normalitas yang dilakukan pada hasil belajar IPA di kelas kontrol diperoleh $X_{\text {hitung }}^{2}=$ $\sum \frac{\left(f_{0}-f_{e}\right)^{2}}{f_{e}}=5,192$. Harga $X^{2}$ hit yang diperoleh dari kelompok kontrol adalah $X_{\text {hitung }}^{2}=\sum \frac{\left(f_{0}-f_{e}\right)^{2}}{f_{e}}$ $=5,192$. Harga tersebut kemudian dibandingkan dengan harga $X_{\text {tabel }}^{2}$ dengan $\mathrm{dk}=3$ dan taraf signifikan $5 \%$ sehingga diperoleh harga $X_{\text {tabel }}^{2}=7,815$, karena $X_{\text {hitung }}^{2}<X_{\text {tabel }}^{2}(5,192<7,815)$ maka $\mathrm{H}_{0}$ diterima atau $\mathrm{H}_{\mathrm{a}}$ ditolak. Ini berarti sebaran data hasil belajar IPA kelompok kontrol berdistribusi normal.

Uji homogenitas varians ini dilakukan berdasarkan data penguasaan kompetensi pengetahuan IPA yang meliputi data kelompok eksperimen melalui media komik berwarna dan kelompok kontrol melalui tanpa media komik berwarna. Jumlah masing-masing unit analisis adalah 27 untuk kelompok eksperimen dan 24 untuk kelompok kontrol. Uji homogenitas varians dalam penelitian ini menggunakan uji $\mathrm{F}$ Ketentuan harga $\mathrm{F}_{\text {hitung }}$ yang diperoleh dibandingkan dengan $\mathrm{F}_{\text {tabel }}$ pada taraf signifikan $5 \%$ dengan derajat kebebasan untuk pembilang $(\mathrm{dk})=\left(\mathrm{n}_{1}-1\right)=$ (24-1) dan derajat kebebasan untuk penyebut $(\mathrm{dk})=\left(\mathrm{n}_{2}-1\right)=(27-1)$.

Berdasarkan hasil uji homogenitas varians pada kelas eksperimen dan kelas kontrol diperoleh hasil diperoleh hasil yang menunjukkan bahwa $F_{\text {hitung }}=1,09$ dan $F_{\text {tabel }}=1,99$ sehingga dapat disimpulkan $F_{\text {hitung }}<F_{\text {tabel }}$ dan data bersifat homogen. Jadi berdasarkan analisis data yang dilakukan, hasil belajar IPA pada kelas eksperimen dan kelas kontrol berdistribusi normal dan homogen sehingga bisa dilanjutkan pada pengujian hipotesis menggunakan uji-t sampel independent (tidak berkorelasi) dengan rumus polled varians. Kriteria pengujiannya adalah $\mathrm{H}_{0}$ ditolak jika $t_{\text {hitung }}>t_{\text {tabel }}$ dan $\mathrm{H}_{0}$ diterima jika $t_{\text {hitung }}<t_{\text {tabel. }}$. pengujian dilakukan pada taraf signifikan $5 \%$ dengan derajat kebebasan $\mathrm{db}=\mathrm{n}_{1}+\mathrm{n}_{2}-2$.

Hasil analisis Uji-t dengan rumus polled varians diperoleh $t_{\text {hitung }}$ sebesar 4,75 sedangkan $t_{\text {tabel }}$ dengan $\mathrm{db}=49$ pada taraf signifikan $5 \%$ adalah 1,67. Hasil perhitungan menunjukkan bahwa $t_{\text {hitung }}>t_{\text {tabel }}$ yang terlihat dari $t_{\text {hitung }}(4,75)$ lebih besar dari $t_{\text {tabel }}(1,67)$ sehingga $H_{0}$ ditolak dan $\mathrm{H}_{1}$ diterima. Hal ini berarti terdapat perbedaan yang siginifikan hasil belajar IPA antara kelompok siswa yang dibelajarkan dengan menggunakan media komik berwarna dan kelompok siswa yang dibelajarkan tanpa menggunakan media komik berwarna pada siswa kelas II SD di gugus II Kecamatan Kubutambahan tahun pelajaran 2017/2018.

Untuk mengetahui pengaruh media komik berwarna terhadap hasil belajar IPA siswa kelas II SD di Gugus II Kecamatan Kubutambahan dapat dilihat dari rata-rata post-test pada kelompok siswa yang dibelajarkan dengan media komik berwarna sebesar $(22,88)$ dan rata-rata kelompok siswa yang tidak dibelajarkan dengan media komik berwarna sebesar $(18,50)$ Perhitungan lengkap dapat dilihat ada lampiran 10 halaman 210. Dengan demikian dapat disimpulkan bahwa siswa penggunaan media komik berwarna berpengaruh secara signifikan terhadap hasil belajar IPA siswa kelas II SD di Gugus II Kecamatan Kubutambahan Tahun Pelajaran 2017/2018. 
Berdasarkan penelitian yang dilakukan, terdapat perbedaan rata-rata pada kelompok eksperimen dan kelompok kontrol. kelompok siswa yang dibelajarkan dengan media komik berwarna memiliki hasil belajar yang tinggi. Tinjauan ini didasarkan pada rata-rata skor hasil belajar IPA siswa. Rata-rata skor hasil belajar IPA siswa yang dibelajarkan dengan media komik berwarna adalah 22,88 berada pada kategori tinggi dan rata-rata skor hasil belajar IPA siswa yang mengikuti pembelajaran tanpa menggunakan media komik berwarna adalah 18,50 berada kategori sedang. Dari perolehan nilai pada Ujian Akhir Sekolah pada kedua kelompok dapat diketahui bahwa kedua kelompok awalnya memiliki kemampuan setara, lalu setelah diberikan treatment yang berbeda perolehan kompetensi pengetahuan IPA mengalami perbedaan yang signifikan. Yaitu dilihat dari nilai rata-rata hasil belajar IPA kelompok eksperimen lebih tinggi dibandingkan dengan nilai rata-rata kelompok kontrol. Terdapat beberapa faktor yang menyebabkan media komik berwarna berpengaruh terhadap hasil belajar IPA siswa.

Faktor pertama, pada saat mengikuti pembelajaran dengan media komik berwarna siswa terlihat bersemangat karena dianggap sesuatu yang baru dan menarik, karena adanya tokoh kartun berupa Upin dan Ipin . Selain itu siswa penasaran dengan media komik berwarna dan sangat antusias. Proses pembelajaran diawali dengan membagikan media komik berwarna, selanjutnya siswa disuruh membaca komik sesuai dengan episode materi yang akan dipelajari. Setelah siswa membaca komik, guru memberikan pertanyaan terkait pembahasan yang ada dikomik dan guru menjelaskan dengan cara bertanya jawab dan siswa merespon pertanyaan dari guru. Siswa dibagikan LKS oleh guru baik secara individu atau kelompok. Jika dalam bentuk kelompok, maka siswa melakukan diskusi dengan aktif dan saling bekerjasama dalam menyelesaikan soal-soal yang terdapat dalam LKS.

Setelah selesai menyelesaikan LKS baik secara individu atau kelompok, LKS dibahas secara bersama-sama. Jika berkelompok maka setiap kelompok membacakan hasil diskusinya di depan kelas. Kelompok yang menjawab pertanyaan dengan benar baik secara individu atau kelompok, diberikan bintang oleh guru dan siswa harus menyimpan baik-baik bintang yang diberikan oleh guru. selanjutnya, 3 siswa yang paling banyak mengumpulkan bintang baik secara individu dan kelompok maka akan diberikan hadiah.

Faktor kedua, adanya perpaduan warna yang menarik dan di dalam media komik berwarna disertai dengan permainan-permainan yang menarik dengan menempel dan memasangkan, sehingga siswa lebih semangat dan tidak mudah bosan. Jadi, siswa seperti belajar sambil bermain, tidak mudah bosan, dan menikmati pembelajaran. Berbeda dengan pembelajaran tanpa media komik berwarna yang terjadi selama pembelajaran IPA di kelompok kontrol.

Kegiatan pembelajaran dilakukan dengan cara menyampaikan materi kepada siswa yang diselingi sedikit tanya jawab kemudian diikuti dengan pemberian tugas individu serta sangat minim penggunaan media pembelajaran. Pembelajaran seperti ini yaitu tanpa media pembelajaran, membuat siswa merasa bosan dan sulit untuk memahami materi pelajaran. Salah satu faktor yang mempengaruhi keberhasilan dalam pembelajaran adalah penggunaan media pembelajaran yang sesuai dan menciptakan pembelajaran yang menyenangkan, menantang, menarik, aktif, dapat menimbulkan, dan media merupakan alat bantu yang dapat membantu seorang guru dan siswa dalam mempermudah proses pembelajaran (Wati, 2016). Dengan demikian, hasil belajar siswa mengalami peningkatan setelah siswa antusias dan tertarik serta semangat, bermain sambil belajar dalam pembelajaran.

Hasil penelitian ini sejalan dengan hasil dari penelitian yang sejenis yang dilakukan oleh Pramadi dkk (2013) dengan judul "Pengaruh Penggunaan Komik Berorientasi Kearifan Lokal Bali Terhadap Motivasi Belajar dan Pemahaman Konsep Fisika". Penelitian tersebut menunjukkan terdapat pengaruh yang signifikan media pembelajaran terhadap motivasi belajar dan pemahaman konsep secara bersama-sama dan menunjukkan bahwa skor prestasi atau pemahaman siswa untuk kelompok eksperimen adalah 76, sedangkan kelompok kontrol adalah 69. Ini berarti bahwa pembelajaran menggunakan media komik hasilnya lebih signifikan di banding kelompok kontrol.

Berdasarkan perhitungan uji-t, terbukti bahwa terdapat perbedaan yang signifikan hasil belajar IPA antara kelompok siswa yang dibelajarkan dengan menggunakan media komik berwarna dan kelompok siswa yang dibelajarkan tanpa menggunakan media komik berwarna. Selain itu diperoleh bahwa rata-rata kelompok eksperimen lebih besar dari rata-rata kelompok kontrol, maka dapat disimpulkan bahwa penggunaan media komik berwarna berpengaruh secara signifikan terhadap hasil belajar IPA siswa kelas II SD di Gugus II Kecamatan Kubutambahan Tahun Pelajaran 2017/2018. 


\section{Simpulan dan Saran}

Berdasarkan hasil pengujian hipotesis dengan perhitungan uji-t diperoleh $t_{\text {hitung }}$ yaitu sebesar 4,75 lebih besar dari $t_{\text {tabel }}$ yaitu 1,67 yang diuji pada taraf signifikan $5 \%$ dengan derajat kebebasan 49. Hal ini berarti terdapat perbedaan yang signifikan hasil belajar IPA antara kelompok siswa yang dibelajarkan dengan menggunakan media komik berwarna dan kelompok siswa yang dibelajarkan tanpa menggunakan media komik berwarna pada siswa kelas II SD di Gugus II Kecamatan Kubutambahan Tahun Pelajaran 2017/2018. Selain itu berdasarkan perolehan rata-rata hasil belajar IPA kelompok eksperimen yaitu 22,89 > rata-rata hasil belajar IPA kelompok kontrol yaitu 18,50. Dengan demikian, dapat disimpulkan bahwa penggunaan media komik berwarna berpengaruh secara signifikan terhadap hasil belajar IPA siswa kelas II SD di Gugus II Kecamatan Kubutambahan Tahun Pelajaran 2017/2018. Adapun saran yang dapat diajukan dalam penelitian ini ada empat antara lain: 1) Disarankan kepada guru agar menggunakan media pembelajaran berupa komik berwarna khususnya dalam mata pelajaran IPA dan mata pelajaran lain pada umumnya dalam upaya meningkatkan hasil belajar. Melalui media komik berwarna kemampuan siswa dalam memahami konsep akan meningkat, selain itu komik berwarna dengan gambar atau tokoh kartun dapat menambah minat siswa untuk belajar. 2) Disarankan kepada kepala sekolah agar membimbing para guru dalam memilih, membuat, dan menerapkan media pembelajaran yang tepat dan sesuai dengan perkembangan siswa sehingga dapat meningkatkan hasil belajar siswa. 3) Disarankan kepada peneliti lain agar dapat menggunakan laporan hasil penelitian ini sebagai acuan kepustakaan dalam melakukan penelitian yang sejenis.

\section{Daftar Pustaka}

Bundu, Patta. 2006. Penilaian Keterampilan Proses dan Sikap Ilmiah Dalam Pembelajaran Sains Sekolah Dasar. Jakarta: Departemen Pendidikan Nasional Direktorat Jenderal Pendidikan Tinggi Direktorat Ketenagaan.

KBBI.2018. Kamus Besar Bahasa Indonesia (KBBI). Online tersedia pada: http://kbbi.web.id/pembelajarankondusif. Diakses 10 Maret 2018.

Khusniati, M., S.D. Pamelasari. 2014. Penerapan Critical Review terhadap Buku Guru IPA Kurikulum 2013 untuk Mengembangkan Kemampuan Mahasiswa dalam Menyusun Perangkat Pembelajaran Berpendekatan Saintifik. Jurnal Pendidikan IPA Indonesia Vol. 3 No. 2 Hal. 168-176. Tersedia Pada: http://journal.unnes.ac.id/nju/index.php/jpii.

Novianti, Riska dwi. 2010. Pengembangan Media Komik Pembelajaran Matematika untuk Meningkatkan Pemahaman Bentuk Soal Cerita Bab Pecahan Pada Siswa Kelas V SDN Ngembung. Jurnal Teknologi Pendidikan Vol 10 No. 1. Universitas Negeri Surabaya.

Pramadi, I Putu Wina Yasa. 2013. Pengaruh Penggunaan Komik Berorientasi Kearifan Lokal Bali Terhadap Motivasi Belajar dan Pemahaman Konsep Fisika. E- Journal Progam Pasca Sarjana Volume 3. Singaraja: Universitas Pendidikan Ganesha.

Rusman, 2015. Pembelajaran Tematik Terpadu Teori, Praktik dan Penilaian. Jakarta: PT Raja Grafindo.

Samatowa, Usman. 2006. Bagaimana Membelajarkan IPA di Sekolah Dasar. Jakarta: Departemen Pendidikan Nasional Direktorat Jendral Pendidikan Tinggi Direktorat Ketenagaan.

Sulthon. 2016. Pembelajaran IPA yang Efektif dan Menyenangkan Bagi Siswa Madrasah Ibtidaiyah (MI). Elementary Vol. 4 J No. 1 Hal. 38-54. Tersedia Pada: http://journal.stainkudus.ac.id/index.php/elementary/article/download/1969/pdf.

Sumiyadi, Kasmadi Imam Supardi, Masturi. 2015. Pengembangan Perangkat Pembelajaran Ipa Berbasis Inkuiri Dan Berwawasan Konservasi. Journal of Innovative Science Education VI. 4 No. 1 Hal. 1-8. Tersedia Pada: http://journal.unnes.ac.id/sju/index.php/jise. 
JP2, Vol 2 No 3, Tahun 2019

p-ISSN : 2614-3909 e-ISSN : 2614-3895

Susanto, Ahmad. 2013. Teori Belajar dan Pembelajaran di Sekolah Dasar. Jakarta: Kencana.

Suwatra, dkk. 2015. Buku Ajar Belajar dan Pembelajaran Sekolah Dasar. Singaraja: Jurusan Pendidikan Guru Sekolah Dasar Fakultas IImu Pendidikan Universitas Pendidikan Ganesha.

Wati, Ega rima. 2016. Ragam Media Pembelajaran. CV Solusi Distribusi: Kata Pena. 